p-ISSN: 2308-4944 (print) e-ISSN: 2409-0085 (online)

Tashkent, Uzbekistan

Year: 2017 Issue: 03 Volume: 47

Published: 23.03.2017 http://T-Science.org

SECTION 24. Sociological research

\title{
SOCIAL ADVERTISING: ITS UNDERSTANDING AND ROLE IN PUBLIC CONSCIOUSNESS
}

\author{
Abstract: In this article the understanding, role, functions and the main aspects of influence of social \\ advertising on public opinion and public consciousness are considered. \\ Key words: advertising, social advertising, public opinion, public consciousness, humanization, society, non- \\ commerce advertising. \\ Language: English \\ Citation: Isanova G (2017) SOCIAL ADVERTISING: ITS UNDERSTANDING AND ROLE IN PUBLIC \\ CONSCIOUSNESS. ISJ Theoretical \& Applied Science, 03 (47): 59-62. \\ Soi: http://s-o-i.org/1.1/TAS-03-47-13 \\ Doi: crossef https://dx.doi.org/10.15863/TAS.2017.03.47.13
}

\section{Introduction}

Social advertising is non-commercial information aimed at achieving socially significant goals: combating harmful habits (drug addiction, alcoholism, smoking), promoting healthy lifestyle, drawing public attention to important questions of state importance, state projects, information about the location of special services (fire, police, ambulance).

Social advertising does not sell anything; it is aimed at achieving charitable goals, improving public welfare. Its goal is to attract attention to the problem; influence on views, on legislation or on changing behavior toward what seems desirable for society. It is the propaganda of normal relationships between people - in the family, in a collective, in society. It is the urge to keep the laws and do good, to keep health and not to lose heart.

\section{Materials and Methods}

In the whole world, the notion of noncommercial advertising and public advertising correspond to the notion of social advertising. "Noncommercial advertising is advertising sponsored by or for the benefit of non-profit institutions and aimed at stimulating donations, encouraging people to vote in favor of others or draw attention to the affairs of society" [1]. "Public (social) advertising conveys a message that propagates any positive phenomenon. Professionals create it for free, place and time in the media are also provided on a non-commercial basis" [2].
In the United States the term public service advertising (PSA) is used to refer to this type of advertising. The subject of the PSA is an idea that must have a certain social value. The purpose of this type of advertising is "to change the attitude of the public to any problem, and in the long term - to create new social values".

Social advertising is advertising not a specific product, but some "attitude to the world". Social advertising is a way of forming a relationship to the surrounding reality. This is a kind of method to suppress the indifference of society to social problems (drug addiction, alcoholism, crime, environmental pollution), to the problems of the state (the revival of patriotism, the well-being of family relations, the fulfillment of civil duties of the population).

In the advertising space, social advertising coexists with commercial advertising, but, thanks to its themes, takes a special place. If commercial advertising works in the market of goods and services, then social - serves to the humanization of society and the formation of its moral values. If commercial advertising changes behavioral models in society from an economic point of view, then the social one - from a humanistic, social point of view.

Social advertising can be distributed through a wide range of information transfer channels. These include posters, screensavers, clips, billboards, leaflets, badges, emblems on consumer goods, graffiti, computer graphics, comics, photographs and cartoons. Works can also be presented in literary 
form in the form of scenarios of performances, slogans, poems, ditties, fairy tales, reports, feuilletons and fables.

In 1906 the American Civil Association placed an advertisement calling for the protection of the Niagara Falls from the harmful actions of electric companies. This year can be considered the year of birth of social advertising.

After the Second World War it acquired modern forms. Today, it is vital for various nonprofit institutions (church, medical institutions, higher education institutions, schools). In the US social advertising is treated as a kind of medicine used to prevent diseases of society. This is its mission.

Social advertising can perform different functions and tasks, but its main goal is to become a kind of regulator of society, a way of positive adjustment of its life activity. Given such features of advertising as repetitiveness, mass character, emotional saturation it can be argued that much depends on the quality of social advertising in the management of society. It can shape moral needs and positive stereotypes and improve social relations. Advertising motto "Call your parents!" against the background of a well-chosen roller penetrates deep into the brain, contributes to the awareness of each person of their responsibility for their fathers and mothers.

Advertising does not simply call for certain actions, but draws an ideal picture in which these actions are shown, serve as role models or, on the contrary, are condemned. Advertising contains not only a picture, but also music. All of these together acts very effectively. In the context of increasing penetration of the screen culture and its impact on the behavior of modern man, the role of social advertising is growing. By the degree of influence on the younger generation, as well as on creative saturation and persuasiveness, advertising competes with such social institutions as home and school, literature and music. For various reasons, advertising seems to sometimes dominate its influence. Advertising forms in society certain ideas about values and styles of life. In the face of the lack of personal communication and the increased impact of the media on the value system of modern man, social advertising is called upon to influence people's behavior, to promote the formation of positive moral standards and patterns. Of course, social advertising can not compensate for the shortcomings of upbringing and fulfill it as a complex task. Nevertheless, the objective processes of the historical development of modern society require the activation of attention to this problem.

The essence of social advertising is that it "is aimed at achieving charitable goals" and socially beneficial results. Under the latter is understood the improvement of the criminal situation in the country;
Prevention of the spread of drug addiction and diseases associated with it; Prompting the population to fulfill their duties to the state (military duty, payment of taxes, compliance with regulations, environmental protection). The principles of social advertising exclude the possibility of pursuing commercial or political goals, mentions of specific commercial brands, organizations, brands (articles, models) of goods, as well as political parties and individual politicians.

The main tasks of social advertising are [4]:

- formation of public opinion;

- attracting attention to pressing issues of public life;

- intensification of actions to address them;

- the formation of a positive attitude towards state structures;

- demonstration of social responsibility of business;

- strengthening of socially significant institutions of civil society;

- the formation of new types of social relations;

- changing behavioral patterns of society.

The central function of social advertising is informational (informing about the problem, drawing public attention to it). With regard to social advertising, information can include a warning. For example, "up to $50 \%$ of patients with alcoholism suffer from a violation of sexual functions".

The second function is educational. This function distinguishes social advertising from commercial advertising. Social advertising gives society knowledge of the problems and methods for overcoming them. For example, "be prudent: keep money in several banks in different currencies".

The third function is educational. Social advertising is designed to educate the public about certain behavior and attitudes towards the reality: does not litter, maintain cleanliness, and protect benches in the park and playgrounds. Social advertising calls more often to communicate with parents, take care of children, cherish the culture of their country, love their homeland, etc. Also, social advertising declares important for a given society values. For example, for some countries of the CIS the revival of the citizens' love for their homeland is actual now; the revival of interest in the rich cultural heritage of the country, to a great history.

Legislative regulation of social advertising in our country is carried out on the basis of Article 16 of the Law of the Republic of Uzbekistan "On Advertising" [10]: Social advertising information information on health, environmental protection, energy conservation, crime prevention, social protection and public safety, spirituality and enlightenment, and also other non-commercial information.

The activity of persons engaged in the production and dissemination of social advertising 
information on a gratuitous basis, the transfer of their property (including money) to others for the production and dissemination of social advertising information is recognized as charitable. Such persons enjoy benefits provided for by law [5].

Distributors of advertising are required to place social advertising information in the volume of at least 5 percent of the total annual airtime, printed or advertising space allocated for advertising. At the same time, advertising distributors, whose activities are fully or partially funded from the State budget of the Republic of Uzbekistan, place social advertising information free of charge.

The broadest "field of activity" for social advertising lies in the propaganda of a certain way of life (propaganda function). Social advertising must meet the following requirements.

First of all, it should show a social problem, and most importantly it is the way to solve it. (For example: the call for neatness on the road should be accompanied by a call to fasten the belts and observe the speed limit).

Second, what you should pay attention to is the placement of advertising. For example, it is ineffective to place advertisements of such content as "Give way to ambulance" in public transport, or a poster with the information message "Cross the road on the pedestrian crossing" on the expressway.

The development of social advertising must involve the public. Already at the present time there are many festivals and competitions. People themselves participate in its development, and, consequently, the probability of non-acceptance of publicity declines by several times.

The question of the ethics of social advertising is also important. The creators of social advertising need to remember that their experiments can cause outbreaks of social tension.

Many researchers talk about the existence of the dependence of the positive results of social campaigns, that is, changes in attitude to the object or behavior, on the strength of provoked emotions especially fear. Between the effectiveness of advertising and emotions is observed a direct dependence - the stronger the emotion, the more effective the message.

Without a doubt, advertising using the threat helps to manipulate human behavior. However, any deliberate stimulation of the state of anxiety affects ethical issues. Even if we imagine an experienced, mature person capable of resisting the influence of advertising, one can not exclude that it can negatively affect even him. Thus, advertising can be unacceptable in terms of ethics, even if it pursues noble social goals. Despite the fact that an appeal to a sense of fear can make a message convincing, its use must be carefully thought out in terms of consequences.

Another interesting question is the use of humor and creativity in social advertising.

Humor often helps in solving the communication problem, but can also destroy the message. It is known that the most significant and affecting the effectiveness of advertising are such factors as quality, utility and accessibility (understandability). In my opinion, humor or shocking creativity can be used in social advertising, but they should not be leading, and even more an end in itself, as is often the case in domestic social advertising.

Social advertising in today's world is focused mainly on such issues as healthy lifestyles (including AIDS prevention), compliance with traffic rules, calling for civil duties (tax payment, military service, etc.), careful attitude to Nature, patriotism and love for the Motherland, strengthening family relations (including raising the birth rate), fostering a sense of responsibility for the fate of children and socially unprotected strata. The range of problems should be expanded; this is due primarily to the role that social advertising plays in the creation and production of moral and spiritual values. It can spiritually enrich the society; awaken in people the best qualities. Motto "Call your parents!" can be perceived in every family differently and every child in its own way, but it is a question of the moral bar of "normality" in economic, civil and social terms. Social advertising is increasingly acting as the "conscience" and "common sense" of society.

\section{Conclusion}

Due to the peculiarities of advertising communication - repeatability, mass character, verbal accuracy, and emotional saturation - the texts of social advertising can serve as a moral catalyst for the state of society and a positive adjustment of its life activity. An appeal to spiritual values and moral standards can form the needs of a spiritual plan. Social advertising, like psychotherapy, is able to improve social relations. Among the important goals can be called the promotion of the basic principles of environmental ethics; Strengthening and family building, as well as intergenerational links; Formation of respect for people; the development of social capital, the unification of citizens on the basis of a community of interests and goals for solving social and cultural problems. 


\begin{tabular}{l|lrl|l|ll} 
& ISRA (India) & $=\mathbf{1 . 3 4 4}$ & SIS (USA) & $=\mathbf{0 . 9 1 2}$ & ICV (Poland) & $=\mathbf{6 . 6 3 0}$ \\
Impact Factor: & ISI (Dubai, UAE) $=\mathbf{0 . 8 2 9}$ & PUHIL (Russia) $=\mathbf{0 . 2 3 4}$ & PIF (India) & $=\mathbf{1 . 9 4 0}$ \\
& GIF (Australia) & $\mathbf{0 . 5 6 4}$ & ESJI (KZ) & $=\mathbf{1 . 0 4 2}$ & IBI (India) & $\mathbf{= 4 . 2 6 0}$ \\
& JIF & $\mathbf{1 . 5 0 0}$ & SJIF (Morocco) & $=\mathbf{2 . 0 3 1}$ & & \\
\hline
\end{tabular}

\section{References:}

1. Gribok NN (2008) Social'naya reklama: uchebnoe posobie. Moskva, Moskovskiy gumanitarnyy universitet, 2008.

2. Isaev S (2017) Social'naya reklama - chto ehto takoe? Available: www.statya.ru (Accessed: 10.03.2017).

3. Kovaleva AV (2006) Social'naya reklama v Rossii: sostoyanie, problemy, reshenie. Barnaul, Altayskiy universitet, 2006.

4. Kuznecov PA (2010) Social'naya reklama. Moskva, Yuniti-Dana, 2010.

5. Nikolayshvili GG (2008) Social'naya reklama: teoriya i praktika: uchebnoe posobie. Moskva, Aspekt Press, 2008.

6. Ovchinnikova S (2017) «Rossiyskiy i zarubezhnyy opyt razvitiya social'noy reklamy»
Available: $\quad$ http://www.socreklama.ru (Accessed: 10.03.2017)

7. Stepanov EV (2007) Social'naya reklama v Rossii: funkcional'nye i zhanrovo-stilisticheskie osobennosti. Moskva, 2007.

8. Stefanov SI (2004) Reklama i poligrafiya: opyt slovarya-spravochnika. Moskva, Gella-print, 2004.

9. (2009) Social'naya reklama. Moskva, YunitiDana, 2009.

10. (2017) Zakon Respubliki Uzbekistan O reklame Available:

http://lex.uz/pages/getpage.aspx?lact $\mathrm{id}=1715$ (Accessed: 10.03.2017). 